\title{
Post-Truth as Ethical Crisis with the Misuse of Social Media
}

Madhusudan Neupane

msn6ktm@gmail.com/msn_ktm@yahoo.com/2020

Abstract

Post-Truth is a novice concept and it has developed as a radical ideology of post modernization. Post truth has emphasized on political, economic, social, cultural and technological aspects of power holders and its hegemony toward the poor nation. Power holders are misusing all forms of media including social media. Facebook, Twitter/Instagram/ Youtube/Whatsapp etc are especially misused to extend the power of regime. Post-truth prioritizes on disinformation for manipulating the perceptions of the people throughout the world. Social media has accused of misusing secret information. Accuracy, Balance and Credibility are no more in information. Social Media cannot play the role of watchdog of society. It cannot fulfill its duty as a gatekeeper. Media has to promote as a mirror of society but in post-truth ideology, it may not be acceptable in all conditions. In fact, it will destroy the professional standard.

Key words: Post-Truth, Ethical crisis, Social Media, Disinformation,

\section{Introduction}

Post-Truth is a new concept for the people of $21^{\text {st }}$ century. It is a philosophical and political ideology for "the disappearance of shared objective standards for truth" (True Publica, 2019). Truth is an essential part of the information to make positive impact for making responsible society. It believes on emotion, false perceptions and personal belief rather than facts, truth and social reality. Every person in society has been misusing all forms of media including social media. Out of them Facebook, Twitter/Instagram/ Youtube/Whatsapp etc are especially misused to extend the power of regime. It has led to increase disintegration of news outlets along ideological orientations. Ancona (2017) clarified Post-Truth as "Collapse of trust is the social basis of the Post-truth era". Some scholar indicated Post-Truth as an Ideological challenges crisis among the political actors, both domestic and international level. It also misuses democratic norms and values of modern society that strongly believes on social responsibilities. Liberal democracy and its political as well as social institutions are suffering from 'fiduciary' trust crisis (Cosentino, 2020).

The academic discussions initiated in 1990s was a broader vision with historical transformations of media systems and journalism among the world societies has been a hot burning issues amplified in the American Presidential election in 2016. Because of the huge popularity of the term "Post-Truth", It was recommend as a word of the year in Oxford Dictionary for 2016 which was deeply misused in the American Media.

Post-truth is not simply a Western phenomenon because it has also closely linked and touched multiple parts of the world as a mean and means of the popular contents of Social media. Social media spreads fake contents for 
enhancing image by providing on-line rumors, Internet hoaxes, facebook fakes, inflammatory memes, conspiracy theories via anonymous image board and disinformation campaigns by Twitter shape and affect political discourses and events across the globe, i.e. from Myanmar (Asia) to Russia (Europe), from Syria (Middle-east) to Brazil (Latin America ), Nigeria (Africa) to America (North America). Most discussions of post-truth tend to have a Westerncentric focus. Katherine (2017) insisted Post-truth as "relating to circumstances in which objective facts are less influential in shaping public opinion than appeals to emotion and personal belief" (Katherine, 2017).

Similarly, Post-truth has developed as a radical ideology of post modernization, as Cosentino has indicated that Post-truth would not have been possible without economic condition of a nation, such as neo-liberalism, the market empire and the unethical neo-protectionism of a political nature, such as populism and radical nationalism (Cosentino, 2020).

\section{Features of Post-Truth}

Post truth has emphasized on political, economic, social, cultural and technological aspects of power holders and its hegemony toward the poor nation. Post-truth prioritizes on disinformation for manipulating the perceptions of the people throughout the world. Most of the social media strengthen the post-truth scenario. It has located the roots of phenomenon in the trust crisis suffered by liberal democracy and its institutions. Cosentino (2020) argues that posttruth serves as a space for ideological conflicts and geopolitical power struggles that are reshaping the world order. The era of post-truth politics is thus here to stay, and its reach is increasingly global. Post-truth has created problematic political and cultural condition with global ramifications.

\section{Most Popular Issues of Post-Truth Campaign}

Social media has accused of misusing secret information during American presidential election in 2016 including Russian trolls organizing events attended by thousands of unaware American citizens; Turkish pro-government activists amplifying on Twitter conspiracy theories invented via Internet image boards by online subcultures in the United States.

According to the report compiled by Cyber Security Company 'New Knowledge' in collaboration with Columbia University, the disinformation campaign leading up to the 2016 US elections was a part of three strategies.

- Attempted hacking of the voting system

- Cyber-attack of the Democratic National Committee email server

- Collection and distribution of confidential emails to the alternative information site WikiLeakswhich provided inspiration for the so-called Pizzagate conspiracy theory

This is the popular example that demonstrates the dangerous effects of the Internet-driven global diffusion of disinformation and misinformation (Cosentino, 2020). 


\section{Theories of Post-Truth Communication}

\section{a. Conspiracy theory :}

Conspiracy theory started to spread as early as September 11, 2001. This theory explains about an event or set of circumstances resulted as a secret plot by usually powerful conspirators. This theory has not based on evidences. It has related to the faith of the believer. Before the popularity of social media (2007), this theory relied on speculations circulating via chain emails and blogs. It allegedly started among Hillary Clinton's supporters and later spread among followers of the Tea Party movement, eventually reaching the mainstream Republican constituency.

\section{b. Weaponization of Information Theory :}

It is the old strategy, which takes advantage by using the latest available technologies. In this process, the hacker hacks different kind of system and information through social engineering on a grand scale. Some observers suggest that using internet tools for intelligence and as fuel for disinformation campaigns is a new form of "hybrid warfare. The Russian attacks on the 2016 U.S. presidential election and the country's continuing election-related hacking have happened across all three dimensions of cyberspace - physical, informational and cognitive.

\section{c. Managed Democracy Theory :}

Pure democracy has directly related with free press, responsible government, free market economy, freedom of speech and expression, right to information and accountable and credible democratic institutions. Nowadays, democracy has become managed democracy for fulfilling the interest of power holders. All democracies are managed democracies. Political success has been achieved by influencing people and by giving them the illusion of freedom Viadislav Surkov (2014).

\section{d. Information Warfare Theory:}

Information warfare theory covers a vast range of different activities and processes seeking to steal, plant, interdict, manipulate, distort or destroy information. The channels and methods available for doing this covers an equally broad range, including computers, smart phones, real or invented news media, statements by leaders or celebrities, online troll campaigns, text messages, vox pops by the concerned citizens.

\section{Models of Post-Truth Ideology}

a. Misinformation: Misinformation "is the spreading of inaccurate or false information. It is not intended but mistakenly thinking inaccurate while sharing accurate information".

\section{b. Disinformation:}

Disinformation is based on "deliberately spreading false or inaccurate information". It is intentional and blurred. Disinformation campaign might willingly produce misinformed people who in turn unwillingly amplify deliberately false information.

Derakhshan and Wardle (2017) differentiate misinformation and disinformation as follows: 


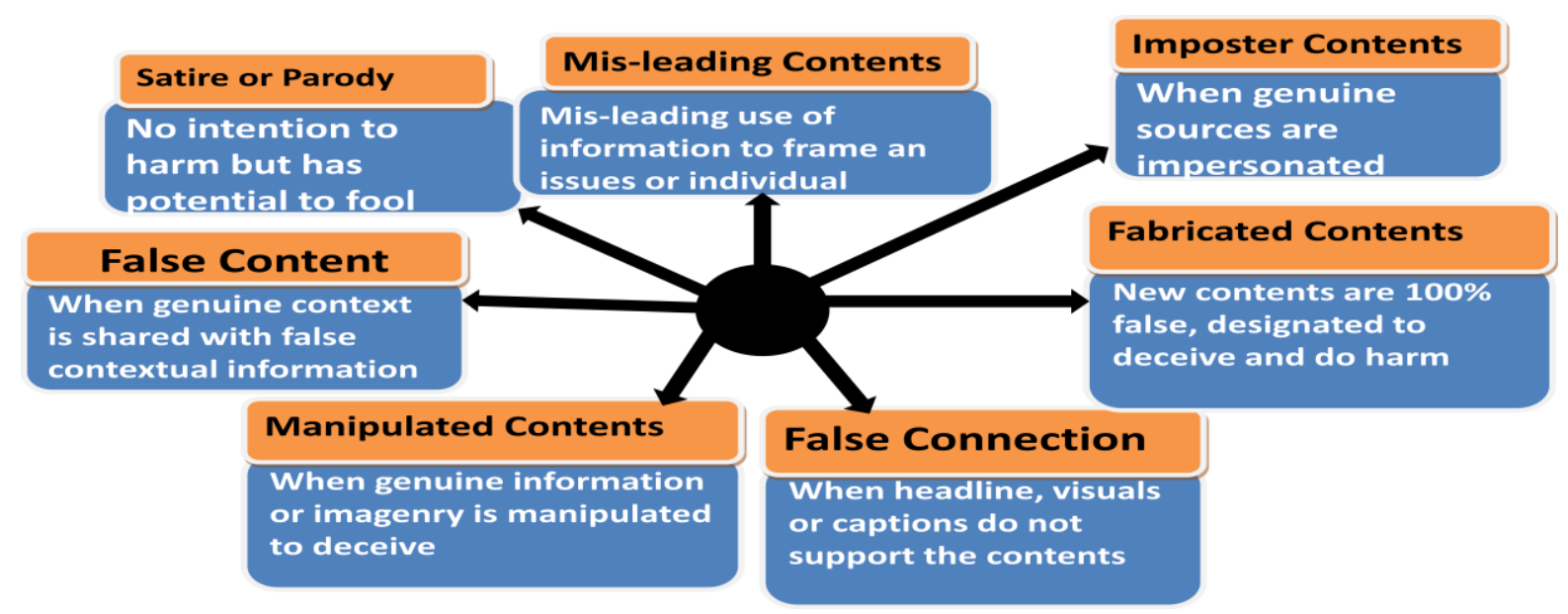

\section{Post-Truth Politics}

Post-truth politics is a broader concept to disseminate state oriented information for manipulating the mind of the people as well as the stakeholders of concerned political parties, officials and nations. It is a kind of conceptual propaganda to make impact among the people of global society for disseminating disinformation and misinformation to make appropriate existence of post-truth politics within concerned parties. It has focused on the role of political parties, their movements and activities of agents officially or unofficially affiliated with State actors, actions by terrorist organizations, in the production and distribution of false or misleading information for manipulative ends with the help of software automation. Many British scholars have taken it as a difficult time. Bartlolo (2019) argues, "We are living in difficult times, in an age of disorientation. We have lost our comfort zones and try to recreate them, like nomads in the desert, trying to find our bearings” (Bartlolo, 2019).

\section{Forms of Post-Truth:}

\section{a. Rumor Bombs :}

Rumors bombs can be elaborated as paradoxical and contain ambiguous claims. It generates confusion and disagreement among the public opinion of the people. It is often the case in post-truth politics. Rumor is not being completely displaced from the public conversation. Rumor bombs have produced a crisis of verification producing managed democracy that benefits elites more than citizens (Harsin, 2012). It provides disinformation.

\section{b. Fake News :}

Fake news is the most popular sub-category of the broader post-truth phenomenon. Fake news, entirely false, rumors, can turn out to be true or contain a small amount of truth. Unlike rumor bombs, fake news is clearly false or fabricated statements. It helps to identify producers of false information. It intends to influence on the social media economy of interest simply in order to generate profit (Corner, 2017).

\section{c. Lies :}

It has inherent linkage on the post-truth condition. Its most visible feature is the noticeable increase of misleading communications and discourses. Fact checking or rumor-debunking web sites are the part of the new economy of 
'truth-markets. Lies and deceptions are structurally connected with contemporary political communication and journalistic practices (Bufacchi 2020). It shows actual situations of social media for promoting Post-Truth communication.

\section{Ethical Crises :}

Accuracy, Balance and Credibility are no more in information. Social Media cannot play the role of watchdog of society. It cannot fulfill its duty as a gatekeeper. Media has to promote as a mirror of society but in post-truth ideology, it may not be acceptable in all conditions. Professional standard will destroy. Media can be lapdog of power holders. Power holders always want to run media as per their own will.

\section{Examples of Post-Truth Communications}

Recent version of postmodernism has changed into post-truth that manipulates every aspect of the society. The most widespread and advanced forms of social media manipulation at the service of influence operations are to be credited to Russian hackers and trolls, especially in the carefully orchestrated strategy aimed at interfering with the 2016 US elections.

\section{Conclusion:}

Post-truth is the new philosophy, emerged during $21^{\text {st }}$ century. Power holders are managed information to disseminate directly for fulfilling their won interest. That avoids truthfulness and ethical standard. Power holders (i.e. businessperson, politician, business tycoon, military strategist) use media in their favor. Post-truth ideology changes normative philosophy of a particular society. The ruling elite control the media and instruments of cultural communication. They can convey the message against public interest.

\section{References :}

- Bartlolo Evatist, 2019, 'Understanding the Post-truth Society: From Fake News, Datafication \& Mass Surveillance to the Death of Truth، The Commonwealth Centre for Connected Learning (3CL) held a conference in Malta's capital, Valletta, on 10-11 October, available at https://connectedlearning .edu.mt /post-truth-society-conference-day-one.

- Bufacchi Vittorio (2020), "Truth, lies and tweets: A Consensus Theory of Post-Truth", Sage Journal, https:/journals.sagepub.com/doi/full/10.1177/0191453719896382

- Corner Jone (2017), "Fake News, Post-truth and Media-political Change", Media, Culture and Society, Sage Journal, 2017, Vol.39(7) 1100-1107, DOI:10.1177/0163443717726743, journals.sagepub.com. /doi/abs/10.1177/0163443717726743?journalCode.mcsa

- Cosentino Gabriele (2020), "Social Media and the Post-Truth World Order", https://doi.org/10.1007/ 9783-030-43005-4_1/ISBN978-3-030-43004-7ISBN978-3-030-43005-4 (eBook) https://doi.org/10.1007 9783-030-43005-4. 
- Derakhshan and Wardle (2017), "Understanding and Addressing the Disinformation Ecosystem", Annenberg School for Communication, December 15-16, 2017, Available at https://firstdraftnews.org/ wpcontent/uploads/2018/03 /The-Disinformation-Ecosystem-20180207-v4.pdf

- Harsin, Jayson (2012), "Attention! Rumor Bombs, Affect, Managed Democracy" 3.0 (August 29, 2012). Available at SSRN: https://ssrn.com/abstract=2138601 or http://dx.doi.org /10.2139/ssrn.2138601.

- Katherine Connor Martin (2017), Head of Oxford English Dictionary Division, 2017 verson/https://www.politico.eu/article/post-truth-enters-oxford-english-dictionary/\#: :text=Post \%2Dtruth $\% 20$ is\%20defined\%20as, of\%200xfordDictionaries head of Oxford's U.S. Dictionaries division

- True Publica (2019), "From post-truth to post-democracy", 20th October 2019 / United Kingdom, https://truepublica.org.uk/united-kingdom/from-post-truth-to-post-democracy/ 